\title{
Interactive Effect of Temperature and Water Stress Induced by Polyethylene Glycol (PEG) on Germination and Recovery of Two Chickpea (Cicer arietinum L.) Cultivars
}

\author{
Atif Hassan Naim"1, Faisal El Gasim Ahmed ${ }^{2}$ \\ ${ }^{1}$ Faculty of Agriculture and Environmental Sciences, University of Gadarif, Al Qadarif, Sudan \\ ${ }^{2}$ Faculty of Agriculture, University of Khartoum, Khartoum, Sudan \\ Email: atif882002@yahoo.com, fgahmed2005@yahoo.com
}

Received 28 September 2015; accepted 18 October 2015; published 22 October 2015

Copyright (C) 2015 by authors and OALib.

This work is licensed under the Creative Commons Attribution International License (CC BY). http://creativecommons.org/licenses/by/4.0/

(c) ()

\begin{abstract}
Effects of different temperatures $\left(10^{\circ} \mathrm{C}, 15^{\circ} \mathrm{C}, 20^{\circ} \mathrm{C}, 25^{\circ} \mathrm{C}\right.$ and $\left.35^{\circ} \mathrm{C}\right)$ and various water potentials $(0$, $-0.25,-0.5,-0.75,-1.0,-1.25,-1.5 \mathrm{MPa})$ on seed germination and early seedling development of two contrasting chickpea (Cicer arietinum L.) cultivars were studied. Different temperatures were applied in an incubator by adjusting the device according to the specific treatments. Water potential treatments were done by using different concentrations of polyethylene glycol (PEG), 8000 (molecular weight). The results showed significant differences between the two cultivars in all characters studied. The cultivar Arman exhibited the higher germination percentage and rate than the cultivar Pirooz. Water stress caused significant reductions in germination parameters at unfavorable temperatures $\left(10^{\circ} \mathrm{C}, 30^{\circ} \mathrm{C}\right.$, and $\left.35^{\circ} \mathrm{C}\right)$. Seeds of both cultivars, which are subjected to high osmotic potentials, had high recovery percentages at the optimum temperature $\left(25^{\circ} \mathrm{C}\right)$. In conclusion, the cultivar Arman seems to be more tolerant to water stress at suboptimal and super optimal temperatures compared with Pirooz.
\end{abstract}

\section{Keywords}

Chickpea, Cicer arietinum, Germination, PEG, Temperature, Water Stress

Subject Areas: Agricultural Science

\section{Introduction}

Chickpea (Cicer arietinum L.), an ancient cool season food legume, is originated from south-eastern Turkey and

How to cite this paper: Naim, A.H. and Ahmed, F.E. (2015) Interactive Effect of Temperature and Water Stress Induced by Polyethylene Glycol (PEG) on Germination and Recovery of Two Chickpea (Cicer arietinum L.) Cultivars. Open Access Library Journal, 2: e2005. http://dx.doi.org/10.4236/oalib.1102005 
the adjoining part of Syria [1]. It is the third most extensively planted grain legume grown in 11.6 million ha with total annual global production of 8.8 million Mt [2]. Chickpea, with $17 \%-24 \%$ protein, $41 \%-51 \%$ carbohydrates and high percentage of other mineral nutrients and unsaturated linoleic and oleic acids, is an important crop for human and animal consumption [3] [4]. Besides being an important cheap source of protein, the crop also plays an important role in the maintenance of soil fertility particularly in the dry rain fed areas [5].

In arid and semi-arid regions, chickpea is often cropped in areas with limited rainfall and grown in saline soils which dry fast; thus drought is always a potential problem [1]. In these areas soil temperature in daytime can be considerably higher than air temperature and the establishment of plants is often limited by temperature when moisture conditions are favorable. Temperature changes may affect a number of processes controlling seed germinability, including membrane permeability and the activity of membrane-bound and cytosolic enzymes [6]. It is very well known that an increase in temperature accelerates the germination process and seedling growth until it reaches the maximum or ceiling temperature, and thereafter there is a sharp decrease in the germination rate [7] [8].

Generally, the effects of soil temperature and water potential on crop establishment are well known. In this regard, many researchers observed strong relationship between germination parameters and water potential at a particular temperature for different crop species [1] [9]. It is well known that the rate of germination and the final germination percentage both decreased with decreasing soil water potential and each species appears to have its own threshold water potential [10] [11]. However, water and temperature interact, such that, for example, a seed's threshold water potential depends largely on temperature, being lowest at the seed's optimum temperature [12].

Little information was found in the literature about the interactive effects of temperature and water stress on germination and early seedling growth of chickpea, therefore, this study was conducted to investigate the effects of temperature and water stress on germination and seedling development of two contrasting chickpea cultivars. The recovery of seed germination from water stress was also determined at different temperatures.

\section{Materials and Methods}

\subsection{Seeds and Experimental Treatments}

Seeds of two chickpea cultivars; namely, Pirooz (desi-type) and Arman (Kabuli-type) were obtained from ICARDA. Seeds were surface sterilized in $1 \%$ sodium hypochlorite $(\mathrm{NaOCl})$ for $3 \mathrm{~min}$, subsequently washed with deionised water and air-dried before being used in experiments to avoid fungus attack. To study the effect of water stress on seed germination and seedling growth a wide range of water potential of PEG-8000 solutions: $0,-0.25,-0.5,-0.75,-1.0,-1.25,-1.5 \mathrm{MPa}$ were prepared according to the procedure described by [13]. PEGinfused water agar Petri-dishes systems were used to impose precisely defined, constant, low water potential treatments. Water potential was lowered by the addition of various amounts of polyethylene glycol (PEG) (molecular weight 8000; Sigma, St Louis, MO) to the water-agar medium. Approximately $20 \mathrm{ml}$ of PEG solution was poured on top of an equal volume of solidified water-agar in a Petri dish, and after $24 \mathrm{~h}$, the solution on top of the dish was poured off and the dish used for experiments. During the $24 \mathrm{~h}$, the PEG diffused into the agar medium, thus lowering its water potential. The $24 \mathrm{~h}$ period was long enough to reach an approximate equilibrium. The medium without PEG was poured in the Petri dishes for the control medium, which gave a water potential for the agar medium of approximately $-0.25 \mathrm{MPa}$ [13] [14]. The experiment was conducted at different temperatures: $10^{\circ} \mathrm{C}, 15^{\circ} \mathrm{C}, 20^{\circ} \mathrm{C}, 25^{\circ} \mathrm{C}, 30^{\circ} \mathrm{C}$, and $35^{\circ} \mathrm{C}$ in darkness.

\subsection{Experimental Design and Measurement of Parameters}

The treatments were placed in a factorial arrangement in a completely randomized design with four replications of 25 seeds each. The number of germinated seeds was counted every 2 days. A seed was considered germinated when the emerging radicle elongated to $2 \mathrm{~mm}$. Four characteristic of seed germination were determined: final germination percentage, mean time to germination (MTG), coefficient of variation of germination time (C.V\%) and germination rate index (GRI).

MTG was estimated according to the following formula:

$$
\text { MTG }=\sum(\mathrm{ni} \times \mathrm{di}) / N,
$$

where: 
$\mathrm{ni}=$ is the number of germinated seeds at day (i),

$\mathrm{di}=$ is the incubation period in days

$\mathrm{N}=$ is the total number of germinated seeds in the treatment.

GRI was estimated according to the following formula:

$$
\mathrm{GRI}=(\mathrm{N} / \mathrm{P}) *\left(\sum \mathrm{ni} \times \mathrm{di}\right),
$$

where:

$\mathrm{N}=$ is the total number of germinated seeds in the treatment,

$\mathrm{P}=$ is the number of incubated seeds at the beginning of the experiment,

$\mathrm{ni}=$ is the number of germinated seeds at day (i),

$\mathrm{di}=$ is the incubation time in days.

All seeds from the previous germination tests which did not germinate after 40 days at different PEG 8000 solutions, were removed and placed in new sterilized Petri dishes with autoclaved filter paper moistened with deionized water, and incubated under the same conditions for additional 40 days to study the recovery of germination. Recovery, for each specific osmotic environment, was calculated as the percentage of ingeminated seeds after PEG treatment to that germinated in the subsequent germination test in deionized water. Germination and recovery percentages were arcsine-transformed before statistical analysis to ensure homogeneity of variance. Data were analyzed using SPSS for windows, version 15. Analysis of variance (ANOVA) was performed to detect differences in all parameters studied followed by least significant difference test (LSD) to estimate least significant range between means.

\section{Results and Discussion}

\subsection{Effect of Temperature, Water Potential and Cultivars on Final Germination Percentage (GP)}

The main effects of cultivar, temperature and water potential and their interactions were significant $(\mathrm{p}<0.05)$ for all investigated characters. Germination was positively affected by increasing temperature up to $25^{\circ} \mathrm{C}$ and thereafter there were a considerable decrease at $30^{\circ} \mathrm{C}$ and $35^{\circ} \mathrm{C}$ (Table 1, Figure 1). Supporting evidence was

Table 1. (A \& B) Effect of different temperatures and water potentials on germination percentage (GP) of two chickpea cultivars, Arman (A) and Pirooz (B) cultivar.

\begin{tabular}{|c|c|c|c|c|c|c|}
\hline \multirow{2}{*}{ Water Potential (MPa) } & \multicolumn{6}{|c|}{ Table 1A. Arman cultivar } \\
\hline & $10^{\circ} \mathrm{C}$ & $15^{\circ} \mathrm{C}$ & $20^{\circ} \mathrm{C}$ & $25^{\circ} \mathrm{C}$ & $30^{\circ} \mathrm{C}$ & $35^{\circ} \mathrm{C}$ \\
\hline 0 & 23.0fA & $55.0 \mathrm{eA}$ & $64.0 \mathrm{cA}$ & 98.3aA & 87.0bA & $60.0 \mathrm{dA}$ \\
\hline-0.25 & $17.0 \mathrm{eB}$ & $48.0 \mathrm{~dB}$ & $56.7 \mathrm{cB}$ & $92.0 \mathrm{aB}$ & $71.0 \mathrm{bB}$ & $48.0 \mathrm{~dB}$ \\
\hline-0.5 & $15.0 \mathrm{fB}$ & $30.0 \mathrm{eC}$ & $43.0 \mathrm{cC}$ & $82.3 \mathrm{aC}$ & $63.0 \mathrm{bC}$ & 33.0dC \\
\hline-0.75 & $11.0 \mathrm{eC}$ & $20.7 \mathrm{dD}$ & $34.0 \mathrm{cD}$ & $59.7 \mathrm{aD}$ & $46.0 \mathrm{bD}$ & $22.0 \mathrm{dD}$ \\
\hline-1.0 & $0 \mathrm{eD}$ & $15.0 \mathrm{dE}$ & $25.7 \mathrm{cE}$ & $43.0 \mathrm{aE}$ & 33.3bE & $13.7 \mathrm{dE}$ \\
\hline-1.5 & OdD & OdF & $15.3 \mathrm{cF}$ & $31.3 \mathrm{aF}$ & $19.0 \mathrm{bF}$ & $0 \mathrm{dF}$ \\
\hline \multirow{2}{*}{ Water Potential (MPa) } & \multicolumn{6}{|c|}{ Table 1B. Pirooz cultivar } \\
\hline & $10^{\circ} \mathrm{C}$ & $15^{\circ} \mathrm{C}$ & $20^{\circ} \mathrm{C}$ & $25^{\circ} \mathrm{C}$ & $30^{\circ} \mathrm{C}$ & $35^{\circ} \mathrm{C}$ \\
\hline 0 & $17.0 \mathrm{eA}$ & $48.7 \mathrm{dA}$ & $56.5 \mathrm{cA}$ & $95.7 \mathrm{aA}$ & $81.7 \mathrm{bA}$ & 58.0cA \\
\hline-0.25 & $14.0 \mathrm{eB}$ & $36.7 \mathrm{~dB}$ & $48.3 \mathrm{cB}$ & 86.3aB & $65.0 \mathrm{bB}$ & $48.0 \mathrm{cB}$ \\
\hline-0.5 & $11.3 \mathrm{eC}$ & $29.7 \mathrm{dC}$ & $30.0 \mathrm{dC}$ & 77.3aC & $54.0 \mathrm{bC}$ & 33.0cC \\
\hline-0.75 & 8.3fD & $22.7 \mathrm{dD}$ & $26.7 \mathrm{cD}$ & 57.3aD & $41.7 \mathrm{bD}$ & $19.0 \mathrm{eD}$ \\
\hline-1.0 & $0 \mathrm{eE}$ & $13.8 \mathrm{dE}$ & $23.7 \mathrm{cE}$ & $40.3 \mathrm{aE}$ & $29.7 \mathrm{bE}$ & $12.3 \mathrm{dE}$ \\
\hline-1.5 & $0 \mathrm{eE}$ & $0 \mathrm{dF}$ & $12.3 \mathrm{cF}$ & 29.7aF & $17.0 \mathrm{bF}$ & $0 \mathrm{dF}$ \\
\hline
\end{tabular}

*The same lowercase letter (s) for temperature in the row and the same uppercase letter (s) for water potential in the column are not significantly different at $5 \%$ probability. 


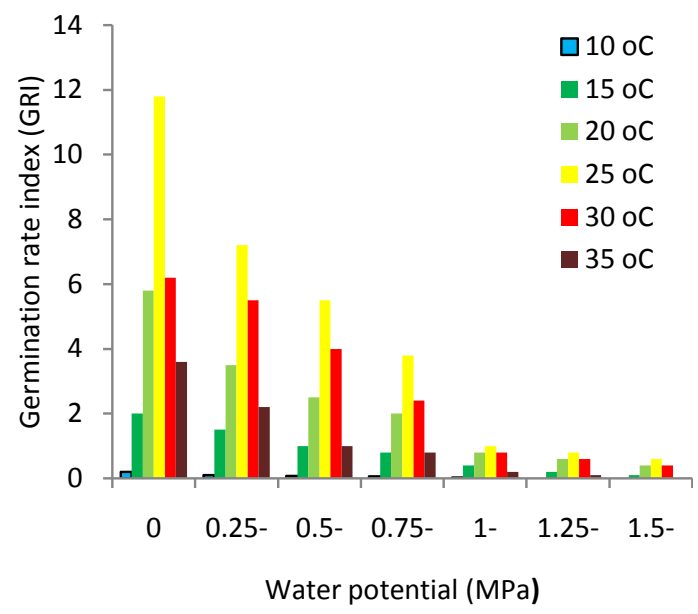

(a)

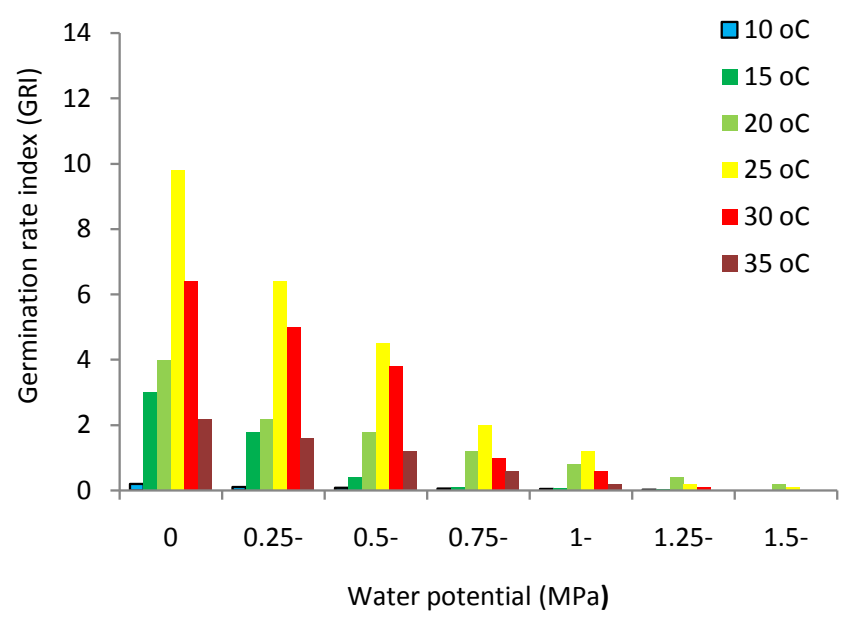

(b)

Figure 1. Germination rate index (GRI) of two chickpea cultivars: Arman (a) and Pirooz (b) at different temperature and water potential regimes.

reported by many researchers [7] [8] [15] [16]. For both cultivars, the final germination percentages and rate of germination were highest at $25^{\circ} \mathrm{C}$ and then started to decrease as temperature increased regardless of water potential (Table 1, Figure 1). However, both cultivars showed the lowest germination percentage and rate of germination at $10^{\circ} \mathrm{C}$ under all water potentials, and at this temperature no cultivar was able to germinate at water potential less than $-0.75 \mathrm{MPa}$ (Table 1, Figure 1). Similarly, as water potential decreased, the final germination and germination rate index (GRI) were significantly decreased in both cultivars at all temperatures (Table 1, Figure 1). These results may be attributed to the fact that large seeded species such as chickpea need more thermal requirements to start germination. The sensitivity of seed germination and seedling growth to low water potential at high temperatures $\left(30^{\circ} \mathrm{C}\right.$ and $\left.35^{\circ} \mathrm{C}\right)$ may be due to the physiological adjustment of seeds to conditions near thermal and/or water potential threshold as reported by many researchers [17] [18]. According to [19], temperature requirement for seed species in arid and semi-arid regions to achieve $60 \%-100 \%$ germination ranges from $15^{\circ} \mathrm{C}-35^{\circ} \mathrm{C}$, with temperature between $20^{\circ} \mathrm{C}-25^{\circ} \mathrm{C}$ being suitable for most species. Moreover, the result showed that the effect of temperature on germination was much greater than water stress. Some researcher such as [20] indicated that since temperature had a strong influence on germination, seeding time should be selected to match the expected temperature required for successful germination at any particular location. They added that early high germination across a large range of temperature might be beneficial for rapid establishment of the crop in semi-arid warm regions where soil moisture in the upper soil surface is available for only short period. The effect of low water potential was pronounced on seed germination of chickpea at different temperatures.

For the two cultivars studied there were a threshold temperature and water potential under which germination does not occur. Similar results were reported by other researcher [7] [8] [14]-[16] [21]. Seed germination of chickpea under suboptimal conditions, simulated by different temperature or water potential in this study, is strongly influenced by genotype (cultivar). The cultivar Arman tended to germinate faster than cultivar Pirooz regardless of temperature and water potential.

The genotypic differences in response to temperature and water potential for final germination percentage and GRI were highly significant. In this regard, the cultivar Arman exhibited higher final germination percentage and rate of germination compared to cultivar Pirooz under all treatments (Table 1, Figure 1).

\subsection{Effect of Temperature, Water Potential and Cultivars on Mean Time to Germination (MTG)}

In contrast to germination percentage and germination rate index, the cultivar Arman had lower MTG compared with the other cultivar Pirooz regardless of temperatures and water potentials (Table 2). Decreasing water potential resulted in substantial delay in MTG for both cultivars at all temperatures studied (Table 2). On the other 
Table 2. (A \& B): Effect of different temperatures and water potentials on mean time to germination (MTG) of two chickpea cultivars, Arman (a) and Pirooz (b) cultivar.

\begin{tabular}{|c|c|c|c|c|c|c|}
\hline \multirow{2}{*}{ Water Potential (MPa) } & \multicolumn{6}{|c|}{ Table 2A. Arman cultivar } \\
\hline & $10^{\circ} \mathrm{C}$ & $15^{\circ} \mathrm{C}$ & $20^{\circ} \mathrm{C}$ & $25^{\circ} \mathrm{C}$ & $30^{\circ} \mathrm{C}$ & $35^{\circ} \mathrm{C}$ \\
\hline 0 & $17.5 \mathrm{bC}$ & $15.0 \mathrm{bC}$ & $8.8 \mathrm{cF}$ & 7.6cE & $26.0 \mathrm{aD}$ & 26.4aED \\
\hline-0.25 & $22.7 \mathrm{bB}$ & $20.3 \mathrm{bcB}$ & 18.0cE & $15.6 \mathrm{dD}$ & 27.5aCD & $29.5 \mathrm{aD}$ \\
\hline-0.5 & 24.3cA & $22.4 \mathrm{cdB}$ & $21.8 \mathrm{cdD}$ & $19.5 \mathrm{dC}$ & 28.3bCD & $32.7 \mathrm{aCD}$ \\
\hline-0.75 & 26.3cA & 25.7cdA & 23.0deCD & $21.0 \mathrm{eBC}$ & $30.0 \mathrm{bBC}$ & $34.8 \mathrm{aBC}$ \\
\hline-1.0 & - & 28.0cA & $26.0 \mathrm{cBC}$ & 25.0cA & $32.6 \mathrm{bAB}$ & $36.1 \mathrm{aAB}$ \\
\hline-1.5 & - & - & $27.4 \mathrm{cAB}$ & $25.7 \mathrm{cA}$ & $34.0 \mathrm{bA}$ & $38.2 \mathrm{aA}$ \\
\hline \multirow{2}{*}{ Water Potential (MPa) } & \multicolumn{6}{|c|}{ Table 2B. Pirooz cultivar } \\
\hline & $10^{\circ} \mathrm{C}$ & $15^{\circ} \mathrm{C}$ & $20^{\circ} \mathrm{C}$ & $25^{\circ} \mathrm{C}$ & $30^{\circ} \mathrm{C}$ & $35^{\circ} \mathrm{C}$ \\
\hline 0 & 23.0bC & $17.4 \mathrm{cD}$ & $17.4 \mathrm{cD}$ & 17.0cC & $30.4 \mathrm{aD}$ & $31.4 \mathrm{aB}$ \\
\hline-0.25 & $26.5 \mathrm{bB}$ & $22.0 \mathrm{cC}$ & 20.6cdCD & $18.5 \mathrm{dBC}$ & 32.3aCD & $33.0 \mathrm{aB}$ \\
\hline-0.5 & $27.8 \mathrm{bAB}$ & $23.7 \mathrm{cBC}$ & $22.4 \mathrm{dC}$ & $20.3 \mathrm{eB}$ & $35.5 \mathrm{aBC}$ & $36.7 \mathrm{aA}$ \\
\hline-0.75 & $30.5 \mathrm{bA}$ & $25.8 \mathrm{cAB}$ & 23.2cdC & $21.3 \mathrm{~dB}$ & 36.7aAB & $38.2 \mathrm{aA}$ \\
\hline-1.0 & - & $27.0 \mathrm{bA}$ & $27.0 \mathrm{bB}$ & 26.2bA & 38.5bAB & 39.3aA \\
\hline-1.5 & - & - & 29.0bAB & 28.6bA & 39.6aA & - \\
\hline
\end{tabular}

*The same lowercase letter (s) for temperature in the row and the same uppercase letter (s) for water potential in the column are not significantly different at $5 \%$ probability.

hand, increasing temperature up to $25^{\circ} \mathrm{C}$ had a positive effect on MTG (both cultivars took less time to $50 \%$ germination). However, high temperatures $\left(30^{\circ} \mathrm{C}\right.$ and $\left.35^{\circ} \mathrm{C}\right)$ resulted in remarkable delay of germination, in both cultivars, regardless of water potential (Table 2). The present study revealed that seed germination of chickpea under suboptimal conditions, simulated by different temperature or water potential in this study, is strongly influenced by genotype (cultivar). The cultivar Arman tended to germinate faster than cultivar Pirooz regardless of temperature and water potential. Moreover, the cultivar Arman had considerably higher recovery percentage from water stress compared with Pirooz. Thus, it obvious that cultivar Arman is more tolerant to water stress than the cultivar Pirooz. The cultivar Arman may have better seedling establishment and increased survival ability than the cultivar Pirooz under water stress conditions. This might be attributed to the fact that the roots of the cultivar Arman could elongate rapidly even under unfavorable soil moisture, thus ensuring the continuation of water supply to the plant.

\subsection{Effect of Temperature, Water Potential and Cultivars on Recovery after Water Stress}

For both cultivars, transfer of non-germinated seeds from PEG solution to the deionized water resulted in substantial increase in recovery percentage at all temperatures except at $10^{\circ} \mathrm{C}$, at which no germination occurred (Figure 2). The results revealed that the cultivar Arman scored the highest recovery percentage from water stress at all studied temperature compared with the other cultivar Pirooz. Surprisingly, the results also indicated that temperature had a remarkable effect on recovery from water stress (Figure 2). In this respect, increasing temperature significantly increased the recovery percentage up to $25^{\circ} \mathrm{C}$, with substantial decrease in recovery percentage at high $\left(30^{\circ} \mathrm{C}\right.$ and $\left.35^{\circ} \mathrm{C}\right)$ temperatures (Figure 2). According to these findings, both chickpea cultivars have tolerance ability to water stress as their seeds resumed germination and recover from water stress. The temperature seems to have major effect on recovery from stress as there is an increase in the recovery with increasing temperature regardless of water potential. The study carried out by [14] [22] [23] indicates the significance of thermo-period in determining the recovery of germination responses of halophyte seeds. 


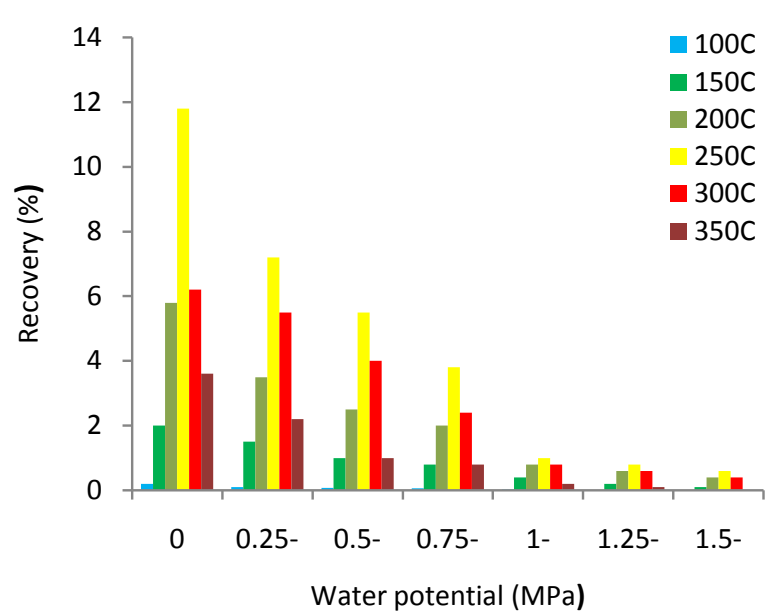

(a)

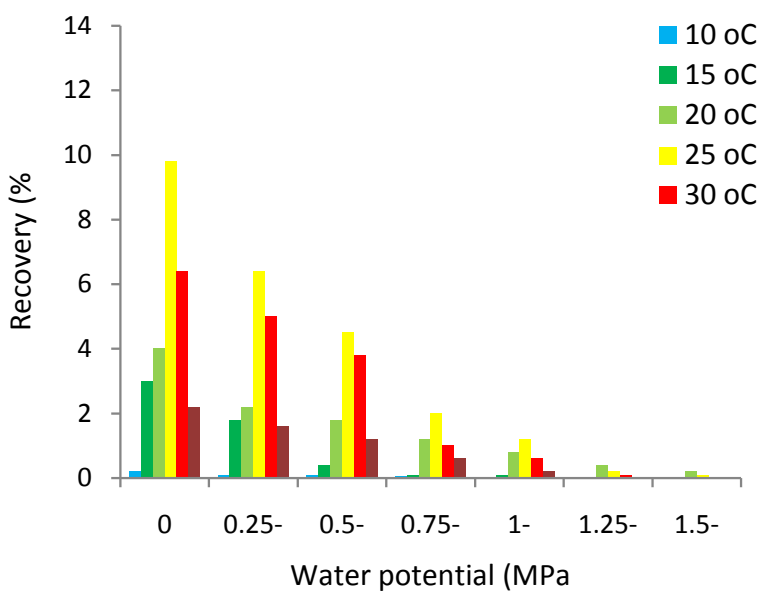

(b)

Figure 2. Percentage recovery of germination at different temperatures of two chickpea cultivars: Arman (a) and Pirooz (b) seeds after transferred from various water potentials of PEG solution to deionized water.

\section{Conclusion}

The present study revealed strong relationship between temperature and water potential on germination and early seedling development plus the recovery from water stress. The study emphasized the genotypic differences of chickpea cultivars with respect to germination and early seedling growth under environmental stresses. Additional work is needed to test the generality of the relationship between the base water potential $(\psi b(50))$, the base temperature $(\mathrm{Tb})$ and germination rate using hydrothermal models to reveal physiological aspects involved in response of chickpea to temperature and water stress.

\section{Acknowledgements}

The authors are very grateful to the kind and generous financial assistance received from the research board of University of Gadraif \& University of Blue Nile in Sudan.

\section{References}

[1] Al-Mutawa, M.M. (2003) Effect of Salinity on Germination and Seedling Growth of Chickpea (Cicer arietinum L.) Genotypes. International Journal of Agriculture and Biology, 5, 226-229.

[2] FAO (2009) Production Year Book. FAO (Food and Agriculture Organization), Rome.

[3] Farshadfar, M. and Farshadfar, E. (2008) Genetic Variability and Path Analysis of Chickpea (Cicer arietinum L.) Landraces and Lines. Journal of Applied Science, 8, 3951-3956. http://dx.doi.org/10.3923/jas.2008.3951.3956

[4] Singh, K.B. (1997) Chickpea (Cicer arietinum L.). Field Crop Research, 53, 161-170. http://dx.doi.org/10.1016/S0378-4290(97)00029-4

[5] Katerji, N., van Hoon, J.W., Handy. A., Mastrorilli, M., Oweis, T. and Malhotra, R.S. (2001) Response to Soil Salinity of Two Chickpea Varieties Differing in Drought Tolerance. Agriculture and Water Management, 50, 83-96. http://dx.doi.org/10.1016/S0378-3774(01)00107-X

[6] Bewley, J.D. and Black, M. (1994) Seeds. Physiology of Development and Germination. 2nd Edition, Plenum Press, New York, p. 445.

[7] Mayer, A.M. and Poljakoff-Mayber, A. (1989) The Germination of Seeds. 4th Edition, Pergamon Press plc, Headington Hill Hall, Oxford OX3 OBW, England, 52-56.

[8] Alvarado, V. and Bradford, K.J. (2002) A Hydrothermal Time Model Explains the Cardinal Temperatures for Seed Germination. Plant cell Environment, 25, 1061-1069. http://dx.doi.org/10.1046/j.1365-3040.2002.00894.X

[9] Macar, T.K., Turan, O. and Ekmekçi, Y. (2009) Effects of Water Deficit Induced by PEG and Nacl on Chickpea (Cicer arietinum L.) Cultivars and Lines at Early Seedling Stages. Gaussian Journal of Science, 22, 5-14.

[10] Khamssi, N.N., Golezani, K.G., Salmasi, S.Z. and Najaphy, A. (2010) Effects of Water Deficit Stress on Field Performance of Chickpea Cultivars. African Journal of Agricultural Research, 5, 1973-1977. 
[11] Teixeira, J. and Perira, S. (2007) High Salinity and Drought Act on an Organ-Dependent Manner on Potato Glutamine Synthetase Expression and Accumulation. Environment and Experimental Botany, 60, 121-126. http://dx.doi.org/10.1016/j.envexpbot.2006.09.003

[12] Fyfield, T.P. and Gregory, P.J. (1989) Effect of Temperature and Water Potential on Germination, Radicle Elongation and Emergence of Mungbean. Journal of Experimental Botany, 40, 667-674. http://dx.doi.org/10.1093/jxb/40.6.667

[13] van der Weele, C.M., Spollen, W.G., Sharp, R.E. and Baskin, T.I. (2000) Growth of Arabidopsis Thaliana Seedlings under Water Deficit Studied by Control of Water Potential in Nutrient-Agar Media Journal of Experimental Botany, 51, 1555-1562. http://dx.doi.org/10.1093/jexbot/51.350.1555

[14] Van den Berg, L. and Zeng, Y.J. (2006) Response of South African Indigenous Grass Species to Drought Stress Induced by Polyethylene Glycol (PEG) 6000. South African Journal of Botany, 72, 284-286. http://dx.doi.org/10.1016/j.sajb.2005.07.006

[15] Covell, S., Ellis, R.H., Roberts, E.H. and Summerfield, R.J. (1986) The Influence of Temperature on Seed Germination Rate in Grain Legumes. I. A Comparison of Chickpea, Lentil, Soybean and Cowpea at Constant Temperatures. Journal of Experimental Botany, 37, 705-711. http://dx.doi.org/10.1093/jxb/37.5.705

[16] Ellis, R.H., Covell, S., Roberts, E.H. and Summerfield, R.J. (1986) The Influence of Temperature on Seed Germination Rate in Grain Legumes. II. Intraspecific Variation in Chickpea at Constant Temperatures. Journal of Experimental Botany, 37, 1503-1515. http://dx.doi.org/10.1093/jxb/37.10.1503

[17] Dahal, P. and Bradford, K.J. (1990) Effects of Priming and Endosperm Integrity on Seed Germination of Tomato Genotypes. II. Germination at Reduced Water Potential. Journal of Experimental Botany, 41, 1441-1453. http://dx.doi.org/10.1093/jxb/41.11.1441

[18] Welbaum, G.E., Tissaoui, T. and Bradford, K.J. (1990) Water Relations of Seed Development and Germination in Muskmelon (Cucumis melo L.). Plant Physiology, 92, 1029-1037. http://dx.doi.org/10.1104/pp.92.4.1029

[19] Baskin, C.C. and Baskin, J.M. (2001) Seeds: Ecology, Biogeography and Evolution of Dormancy and Germination. Academic Press, San Diego, p. 666.

[20] Brar, G.S., Gomez, J.F., McMichael, B.L., Matches, A.G. and Taylor, H.M. (1991) Germination of Twenty Forage Legumes as Influenced by Temperature. Agronomy Journal, 83, 173-178. http://dx.doi.org/10.2134/agronj1991.00021962008300010040x

[21] Khan, M.A. and Ungar, I.A. (1997) Alleviation of Seed Dormancy in the Desert Forb (Zygophylhum simplex L). Pakistan Annals of Botany, 80, 395-400. http://dx.doi.org/10.1006/anbo.1997.0449

[22] Okçu, G., Kaya, M.D. and Atak, M. (2004) Effects of Salt and Drought Stress on Germination and Seedling Growth of pea (Pisum sativum L.). Turkish Journal of Agriculture, 29, 231-242.

[23] Ellis, R.H., Covell, S., Roberts, E.H., Summerfield, R.J. (1986) The Influence of Temperature on Seed Germination Rate in Grain Legumes. II. Intraspecific Variation in Chickpea at Constant Temperatures. Journal of Experimental Botany, 37, 1503-1515. http://dx.doi.org/10.1093/jxb/37.10.1503 